http://dx.doi.org/10.4314/jae.v19i2.5

\title{
Socioeconomic Effects of Farmer-Pastoralist Conflict on Agricultural Extension Service Delivery in Oyo State, Nigeria
}

\author{
Adelakun O.E. \\ Department of Agricultural Extension and Rural Development \\ University of Ibadan, Oyo State, Nigeria. \\ Email: flakyonline@yahoo.com

\section{Adurogbangba B.} \\ Department of Agricultural Extension and Rural Development \\ University of Ibadan, Oyo State, Nigeria.
}

\author{
Akinbile, L.A. \\ Department of Agricultural Extension and Rural Development \\ University of Ibadan, Oyo State, Nigeria. \\ Email: lakinbile@yahoo.com \\ Phone: 08023250454
}

\begin{abstract}
The study examined the socio - economic effect of farmer-pastoralist conflict on family farming in Oyo State, Nigeria. Multi-stage sampling technique was used to select to 60 farmers and 60 pastoralists for the research and were interviewed with structured questionnaire. Results showed that a little above half $(52.6 \%)$ were between the ages of $30-50$ years. The majority (63.3\%) had household size of 5-9 members. Crop damage (63.3\%) and indiscriminate bush burning (46.7\%) were considered the most common causes of conflict between farmers and pastoralists. The majority (71\%) of farmers suffer economic losses from farmer-pastoralist conflicts. About seventy five percent of farmers used more of problem-oriented (e.g. early harvesting/stock disposal) coping strategies while the majority of herdsmen (73\%) used more of emotion-oriented strategies (e.g. use of charms/Vengeance. There was a significant difference $(p=0.000)$ in socioeconomic losses among farmers and pastoralists. Farmers are the worst hit of Farmer-pastoralist conflicts as it affects their family farming. Setting up of a three-tier farmer-herdsmen conflict management committee is recommended.
\end{abstract}

Keywords: Farmers, Pastoralist, Agricultural Extension.

\section{Introduction}

Agricultural production in any country requires an enabling environment to reach its maximum potential. Sustainable development in agriculture, among other things, demands a peaceful co-habitation of producer communities. It is only through cooperation that local communities could implement sustainable 
common pool of resource conservation and management strategies. In addition, stable and harmonious communities are only the ones that are able to be resilient and creative to respond to environmental stresses and sustain their livelihoods rather than those, which are frustrated by the circumstances in their localities. However, an important but somewhat overlooked challenge facing agriculture and rural development in Nigeria is the problem associated with farmer-pastoralist conflicts for arable land. Increasing frustration and impoverishment of farmers occasioned by perennial and extensive farm plot destruction and the ensuing bitter conflicts are eroding the gains of agricultural and rural development interventions. This becomes a problem for extension because the ultimate objective of extension to enhance the living condition of rural households is being threatened.

The increase in pressure resulting from resource degradation and scarcity is aggravating the situation of competition between farmers and pastoralists. In the areas where the two production systems interact, both communities are increasingly considering the option of expansion to each others' holdings. As a result, conflicts are getting recurrent and intensified in many parts of the country. This is supported by Blench (2003) that farmer-pastoralist conflicts are increasing both in terms of recurrent and intensity.

According to Aliyu (2004), conflicts in Nigeria are of diverse types and have been on rapid increase since after the civil war of $1967-1970$. These conflicts are mainly attributable to resource control and divergent value systems in the country. The movement of pastoralist from one area of the country to another is usually caused by the increasing demand for fresh grazing grounds especially during draught period, when the pastoralists move southwards because of the availability of pasture. In most cases, the pastoralists do encounter problems with the local people because farmers' crops were being destroyed by their cattle (Olaleye et al, 2010).

However, a number of measures are being taken to mitigate these seemingly intractable conflicts by government at various levels over the years. For instance, Nigeria has 415 government designated grazing reserves throughout the country, while farmer-herdsmen reconciliatory committees in most conflict prone states have been set up to control resource-based conflicts among farmers and pastoralists. The Nigerian government also continues to carve out new stock routes for herdsmen. Government is also demarcating a 1,400km livestock route from Sokoto State in the northwest, to Oyo State in the southwest and another $2400 \mathrm{~km}$ route from Adamawa State to Cross River State in the delta region. This is in addition to demarcating 175,000 hectares of grazing land, building veterinary service centres and constructing settlements for nomads to use en route at a cost of US\$247 million (IRIN, 2010). Various non-governmental organizations (NGOs) are also responding to this issue though they are more notable for their proximity to amiable donors than for any long-term progress in the field (Blench, 2003). Unfortunately, these conflicts not 
only continue to persist, they are on the rise and fast becoming a nationwide phenomenon.

Currently there are a few systematically gathered and compiled information on the occurrences and magnitude of such conflict. Hence an understanding of the causes and effects of conflict between nomads and farmers in host communities is an important pre-requisite for the realization of the goals of agricultural development policies to which research experts and extension agents are professionally committed. Also there is need to discover and explore the socio-economic effect of farmer-pastoralist conflict on agricultural extension service delivery. This is particularly true if any reasonable success is to be achieved in the agricultural sector that is currently undergoing changing production patterns as a result of market and information-driven intensification through the Agricultural Transformation Agenda (ATA). It seems that there is a lot to be done in the area with regard to policy reforms to address socioeconomic effects of the problem of conflicts in the country especially as it affects the agricultural extension service delivery. This will help to pay adequate attention to the strong relationship between the food security, pastoral productivity and conflict over resources. This paper therefore, examines the various factors responsible for farmer-pastoralist conflict, methods of conflict management adopted for improved relationship among farmers and pastoralists and also the level of socioeconomic losses suffered due to conflict by the respondents. It was hypothesized that no significant difference existed in the effect of conflict on extension service delivery to farmers and pastoralist.

\section{Methodology}

Oyo is an inland state in Southwestern Nigeria which has its capital at Ibadan. It is located between Latitude $7^{0} 2^{1}$ and $9^{0} 1^{1}$ North of the Equator and between Longitude $2^{0} 5^{1}$ and $4^{0} 3^{1}$ East of the Greenwich Meridian. The mean annual rainfall ranges from 56 inches in the south and 46 inches in the north. The population of the study comprises of all farmers and pastoralists in Oyo State, who operate in conflict prone areas and have experienced conflict at one time or the other. Multi-stage sampling technique was used to select respondents from the population of farmers and pastoralists.

Local Government Areas with perennial farmers-pastoralists conflict were: Atisbo, Irepo, Iseyin, Itesiwaju, Iwajowa, Kajola, Olorunsogo, Orelope, Saki East and Saki West.

Stage 1: Thirty percent of the LGAs were randomly selected. The LGAs are Atisbo, Itesiwaju and Saki West.

Stage 2: In each selected LGA, two farming communities were purposively selected because of the fresh report of farmer-pastoralist conflict.

Stage 3: Ten arable crop farmers were randomly selected from each selected farming communities, thus giving a total of 60 farmers. Also, in each of the selected LGAs, 20 cattle herdsmen were randomly selected. This was done by 
randomly selecting four herdsmen each from five transit camps (i.e. 20 herdsmen) in each LGA. This gave a total of 60 herdsmen. A total of one hundred and twenty respondents comprising of sixty farmers and sixty pastoralists were used for the study. Data was collected through the use of interview schedule and analysed using both descriptive statistics (frequencies and percentages) and inferential statistics ( PPMC, chi-square and T-test). The data were analysed at 0.05 level of significant. Respondents were asked to indicate the extent of social and economic losses incurred as a result of farmerpastoralist conflict with a three-point scale of not at all, mild and severe. Respondents were also asked to indicate methods of conflict resolutions adopted in their locality using Yes or No

\section{Results and Discussion}

\section{Personal characteristic of respondents}

The majority $(52.6 \%)$ of the respondents were between the ages of $30-50$ years, while $47.4 \%$ were above 50 years of age (Table 1 ). The study further reveals that most of the farmers $(90 \%)$ and pastoralist $(96.6 \%)$ were males. This agrees with the finding of Olaleye et. al. (2010) which revealed that males are more involved in both farming and pastoral activities. Also, $61.6 \%$ of farmers and $65 \%$ of pastoralists have household size of between 5 and 9 . The implication is that the relatively large family sizes for the two groups may mean more people to cater for and more hands to work on the farm and help with cattle herding. The majority of the farmers (95.0\%) and pastoralist $(93.3 \%)$ were married. This implies that most of the respondents have some responsibilities, therefore marital status is an important factor to be considered in any programme of change to be introduced to the study area since family decision will be required in any activity to be embarked upon. Also, the majority $(93.3 \%)$ of the pastoralists had non-formal education while most $(65.0 \%)$ of the farmers had one form of formal education. This implies that most of the pastoralists are illiterate compared to the farmers who are more literate. This finding agrees with that of Olaleye et. al. (2010) who reported that the majority of nomads do not have formal education when compared to farmers. The result further reveals that $52.1 \%$ of the farmers had 31-50 years farming experience while most (58.3\%) of the pastoralists had 20-40 years experience as pastoralists. This suggests that the farmers had more exposure to farming activities. 
Table 1: Percentage distribution of respondents according to personal characteristics

\begin{tabular}{|c|c|c|}
\hline Personal characteristics & $\%$ Farmers $(n=60)$ & $\begin{array}{l}\text { \% Pastoralist }(n= \\
60)\end{array}$ \\
\hline \multicolumn{3}{|r|}{$x_{1}$} \\
\hline$<30$ & 3.3 & 5.0 \\
\hline $31-40$ & 16.7 & 21.7 \\
\hline $41-50$ & 28.3 & 30.0 \\
\hline $41-60$ & 23.4 & 18.3 \\
\hline $61-70$ & 15.0 & 10.0 \\
\hline $71-80$ & 13.3 & 13.3 \\
\hline$>80$ & & 1.7 \\
\hline \multicolumn{3}{|l|}{ Sex } \\
\hline Male & 90.0 & 96.7 \\
\hline Female & 10.0 & 3.3 \\
\hline \multicolumn{3}{|l|}{ Religion } \\
\hline Christianity & 58.3 & 3.3 \\
\hline Islam & 36.7 & 96.7 \\
\hline Traditional & 5.0 & \\
\hline \multicolumn{3}{|l|}{ Marital status } \\
\hline Single & 1.7 & 0.0 \\
\hline Married & 95.0 & 93.3 \\
\hline Divorced & 0.0 & 1.7 \\
\hline Widowed & 1.7 & 1.7 \\
\hline Separated & 1.7 & 3.3 \\
\hline \multicolumn{3}{|l|}{ Level of education } \\
\hline No formal & 26.7 & 86.7 \\
\hline Primary & 26.7 & 0.0 \\
\hline Secondary & 21.7 & 0.0 \\
\hline Tertiary & 16.7 & 0.0 \\
\hline Adult education & 8.2 & 13.3 \\
\hline \multicolumn{3}{|l|}{ Household size } \\
\hline $1-4$ & 11.7 & 1.7 \\
\hline $5-9$ & 61.6 & 65.0 \\
\hline $10-14$ & 20.0 & 20.0 \\
\hline$>14$ & 6.7 & 13.3 \\
\hline \multicolumn{3}{|c|}{ Years of farming experience } \\
\hline$<20$ years & 15.0 & 18.3 \\
\hline $21-30$ years & 38.3 & 28.4 \\
\hline $31-40$ years & 26.7 & 25.0 \\
\hline $41-50$ years & 10.0 & 15.0 \\
\hline$>50$ years & 10.0 & 13.3 \\
\hline
\end{tabular}

Source: Field survey, 2013

The two groups differed in five out of the fourteen causes of their mutual conflict, (Table 2). This means that the two groups had similar opinions on 65\% of the causes of farmer-pastoralist conflicts. The four areas of disagreement 
are: crop damage (34.2\%; 6.7\%), ethnic rivalry (4\%; 16\%), farm fragmentation $(4 \% ; 21 \%)$, indiscriminate bush burning $(66 \% ; 5 \%)$ and government attitude $(26 \% ; 1 \%)$ for farmers and pastoralists respectively. While farmers, in contrast to the herdsmen, generally believed that crop damage (34.2\%), indiscriminate bush burning (66\%) and government attitude (26\%) are major factors that lead to conflict; herdsmen on the other hand, generally opined that unceasing farm fragmentation by farmers (21\%) and ethnic rivalry (16\%), are responsible for the conflicts. It is important, however, to note that both groups did not agree that low awareness of stock route and depleting soil fertility are causes of conflicts. Table 2 further shows the extent to which conflicts occur among the respondents as a result of each of the identified causes perceived by them in the study area. About $73.3 \%$ of the respondents $(38.3 \%$ farmers, $35.0 \%$ pastoralists) agreed that deliberate hostility by other party always initiate the conflict. $34.2 \%$ farmers and $6.7 \%$ pastoralist indicated that crop damage always triggers conflict between farmers and pastoralist. 59.7\% (55.5\% farmers, $4.2 \%$ pastoralists) of the respondents also indicated bush burning activities as a factor that always result in conflict. However, depleting soil fertility was never a cause of conflict by the respondents $(40.0 \%$ farmers, $41.7 \%$ pastoralist). The difference in perception of farmers and nomads with respect to frequency of causes of conflicts is attributed to the fact that in a conflict situation, there is bound to be an exaggeration of facts and denial of faults by the parties involved. Another reason is that different people have different perception about issues. This finding agrees with that of Tonah (2006) which stated that the most frequent cause of conflict between farmers and pastoralists is the destruction of crops by cattle. This is also supported by Olaleye et. al. (2010) who opined that crop damage and competition for land and water were the predominant factors causing farmer-herder conflict in the study area. 
Table: 2: Percentage distribution of respondents according to frequency of occurrence of the perceived causes of conflict between farmers and pastoralists

\begin{tabular}{|c|c|c|c|c|c|c|c|c|}
\hline Causes of conflicts & $\begin{array}{l}\text { Never } \\
\text { Farmer }\end{array}$ & Pastoralist & $\begin{array}{l}\text { Rarely } \\
\text { Farmer }\end{array}$ & Pastoralist & $\begin{array}{l}\text { Occasionally } \\
\text { Farmer }\end{array}$ & Pastoralist & $\begin{array}{l}\text { Always } \\
\text { Farmer }\end{array}$ & Pastoralist \\
\hline Crop damage & 6.7 & 30.0 & 5.0 & 6.7 & 5.0 & 10.8 & 34.2 & 6.7 \\
\hline $\begin{array}{l}\text { Low awareness of } \\
\text { stock routes }\end{array}$ & 15.0 & 80.8 & 4.2 & 0.0 & 0.0 & 0.0 & 0.0 & 0.0 \\
\hline Competition for land/ water & 33.3 & 38.3 & 0.0 & 4.2 & 6.7 & 5.0 & 7.5 & 5.0 \\
\hline $\begin{array}{l}\text { Ethnic rivalry } \\
\text { Low level of compliance to }\end{array}$ & 56.7 & 8.3 & 0.0 & 0.8 & 5.0 & 12.5 & 3.3 & 13.3 \\
\hline $\begin{array}{l}\text { stock routes } \\
\text { Farm fragmentation }\end{array}$ & 70.8 & 19.2 & 1.7 & 0.8 & 2.5 & 1.7 & 0.8 & 2.5 \\
\hline Declining influence of & 3.3 & 66.7 & 0.0 & 1.7 & 1.7 & 5.8 & 3.3 & 17.5 \\
\hline $\begin{array}{l}\text { traditional rulers } \\
\text { Deliberate hostility by other }\end{array}$ & 10.8 & 65.8 & 1.7 & 10.8 & 0.8 & 4.2 & 2.5 & 5.0 \\
\hline $\begin{array}{l}\text { party } \\
\text { Deliberate hostility by both }\end{array}$ & 0.8 & 2.5 & 7.5 & 6.7 & 4.2 & 5.8 & 38.3 & 35.0 \\
\hline $\begin{array}{l}\text { parties } \\
\text { Indiscriminate bush burning }\end{array}$ & 9.2 & 50.0 & 5.0 & 7.5 & 8.3 & 11.7 & 0.0 & 8.3 \\
\hline Depleting soil fertility & 3.3 & 0.0 & 15.0 & 8.3 & 9.2 & 5.0 & 55.0 & 4.2 \\
\hline Government attitude & $\begin{array}{l}40.0 \\
1.7\end{array}$ & $\begin{array}{l}41.7 \\
19.2\end{array}$ & $\begin{array}{l}3.3 \\
4.2\end{array}$ & $\begin{array}{l}5.8 \\
2.5\end{array}$ & $\begin{array}{l}3.3 \\
40.8\end{array}$ & $\begin{array}{l}0.8 \\
9.2\end{array}$ & $\begin{array}{l}0.8 \\
21.7\end{array}$ & $\begin{array}{l}4.2 \\
0.8\end{array}$ \\
\hline $\begin{array}{l}\text { Stealing of crops } \\
\text { Little respect for traditional } \\
\text { grazing/farming }\end{array}$ & $\begin{array}{l}9.2 \\
43.3\end{array}$ & $\begin{array}{l}6.7 \\
30.0\end{array}$ & $\begin{array}{l}9.2 \\
9.2\end{array}$ & $\begin{array}{l}20.8 \\
4.2\end{array}$ & $\begin{array}{l}13.3 \\
1.7\end{array}$ & $\begin{array}{l}9.2 \\
2.5\end{array}$ & $\begin{array}{l}31.7 \\
1.7\end{array}$ & $\begin{array}{l}16.7 \\
7.5\end{array}$ \\
\hline
\end{tabular}

Source: field survey, b2013

\section{Methods of conflict resolution}

Table 3 shows that most of the respondents (68.9\%) in the study area indicated intervention by law enforcement agencies as one of the methods of conflict resolution, $55.5 \%$ of the respondent indicated dialogue between the parties involved as a means of conflict resolution, $42.5 \%$ opined that they seek the intervention of local community leaders in fostering peace between the parties involved. While farmers generally believed that court verdict $(33.3 \%)$, dialogue between parties involved (37\%) and local community crop farmers intervention $(24.6 \%)$ were major methods of conflict resolution, herdsmen on the other hand, generally opined that payment of compensation to victims ( $29.2 \%$ ), intervention by law enforcement agents $(51 \%)$ and intervention by traditional leaders $(25.5 \%)$, were methods of conflict resolution. It is important, however, to note that both groups did not believe that educating farmers and herders by person or bodies responsible for conflict resolution conflicts is capable of resolving conflict. 
Table 3: Percentage distribution according to the methods of conflict resolution

\begin{tabular}{|c|c|c|}
\hline Method of conflict resolution & $\begin{array}{l}\% \text { Farmers }(n= \\
60)\end{array}$ & $\begin{array}{l}\text { \% Pastoralist }(\mathrm{n}= \\
60)\end{array}$ \\
\hline Intervention by traditional leaders & 10.0 & 25.8 \\
\hline Payment of compensation to victims & 9.2 & 29.2 \\
\hline Court verdicts & 33.3 & 5.0 \\
\hline Dialogue between parties involved & 37.2 & 18.3 \\
\hline $\begin{array}{l}\text { Local community crop farmers/herders } \\
\text { intervention }\end{array}$ & 24.6 & 18.3 \\
\hline $\begin{array}{l}\text { Educating farmers and herders by person } \\
\text { or bodies responsible for conflict resolution }\end{array}$ & 0.8 & 0.0 \\
\hline Intervention by law enforcement agents & 25.8 & 42.5 \\
\hline
\end{tabular}

Source: Field survey, 2013

\section{Social and economic loses among respondents as a result of conflict}

Table 4 shows that the majority of the farmers suffer more losses from farmerpastoralist conflicts, especially economic losses. Reduction in output (20.0\%), loss of properties (28.3\%), and scarcity of food (23.3\%) were regarded as severe economic losses experienced by farmers. A larger percentage (46.7\%) of the farmers indicated loss of properties as a major economic loss encountered as a result of conflict. Very few of the pastoralists considered any of the losses as severe. This implies that farmers suffer more loss than the pastoralists. Reduction in output and income of crop farmers are as a result of the destruction of crops by cattle and indiscriminate bush burning. 
Table: 4: Percentage distribution according to social and economic loses among respondents as result of conflict

\begin{tabular}{|c|c|c|c|c|}
\hline \multirow[t]{2}{*}{ Socio-economic losses } & \multicolumn{2}{|c|}{ Extent of loss } & \multirow[b]{2}{*}{$\begin{array}{l}\text { Pastoralist } \\
\text { Severe }\end{array}$} & \multirow[b]{2}{*}{ Mild } \\
\hline & $\begin{array}{l}\text { Farmers } \\
\text { Severe }\end{array}$ & Mild & & \\
\hline Reduction in output & 20.0 & 23.3 & 3.3 & 21.7 \\
\hline Loss of properties & 28.3 & 18.3 & - & 1.7 \\
\hline Loss of produce in storage & 18.3 & 10.0 & 1.7 & 1.7 \\
\hline Inability to repay loan & 21.7 & 6.7 & 1.7 & 3.3 \\
\hline Migration of labour & 8.3 & 10.0 & 5.0 & 3.3 \\
\hline Reduced access to land & 3.3 & 5.0 & 1.7 & 3.3 \\
\hline Scarcity of food items & 23.3 & 11.7 & 8.3 & 5.0 \\
\hline Displacement & 8.3 & 10.0 & 13.3 & 8.3 \\
\hline Disruption of group membership & 3.3 & 3.3 & 5.0 & 3.3 \\
\hline $\begin{array}{l}\text { Mutual distrust among the various parties to } \\
\text { dispute }\end{array}$ & 6.7 & 13.3 & 8.3 & 10.0 \\
\hline \multirow{2}{*}{$\begin{array}{l}\text { Constraints in mobility } \\
\text { Interruption in the education of children }\end{array}$} & 3.3 & 5.0 & 3.3 & 3.3 \\
\hline & 5.0 & 6.7 & 5.0 & 8.3 \\
\hline Increased stress & 20.0 & 10.0 & 3.3 & 8.3 \\
\hline Impairment and disabilities & 3.3 & 8.3 & 1.7 & 15.0 \\
\hline
\end{tabular}

Source: Field survey, 2013

\section{Extent to which farmers-pastoralists conflicts affect agricultural extension service delivery}

Table 5 reveals that a little above half $(56.7 \%)$ indicated that the effect of conflict on continued use of adopted technology is severe, also $35.9 \%$ of the respondents considered the effect of conflict on availability to extension service as severe. About $29 \%$ and $33.3 \%$ affirmed that there was mild effect of conflict on adoption of improved technology and continued use of adopted technology. The fact that the responses of the sampled respondents were low especially from the pastoralists suggests that less impact of extension services were felt in the study area. This is corroborated by the response of one of the respondents during the focus group discussion that "The days of substantive agricultural extension activities were during the time of ONADEP but it is no longer effective.....Regardless of the effectiveness of extension service 
delivery, any improved technology we adopt won't take nomads a single day to scatter...."

This agrees with Adisa (2011), who revealed that incessant resource-based conflicts between farmers and herdsmen continue to undermine the impact of agricultural extension service delivery in Nigeria.

Table 5: Extent farmers-pastoralists conflicts affect agricultural extension service delivery

\begin{tabular}{lllcc}
\hline Items & $\begin{array}{l}\text { Severe\% } \\
\text { Farmer }\end{array}$ & Pastoralist & $\begin{array}{c}\text { Mild\% } \\
\text { Farmer }\end{array}$ & Pastoralist \\
\hline $\begin{array}{l}\text { Availability of extension } \\
\text { Services }\end{array}$ & 22.5 & 5.0 & 3.4 & 3.4 \\
$\begin{array}{l}\text { Access to extension services } \\
\text { Extension delivery methods }\end{array}$ & 13.4 & 1.6 & 1.6 & 6.6 \\
$\begin{array}{l}\text { Adoption of improved } \\
\text { technologies }\end{array}$ & 29.2 & 3.4 & 13.4 & - \\
$\begin{array}{l}\text { Continued use of adopted } \\
\text { technologies }\end{array}$ & 56.7 & 5.8 & 29.2 & \\
\hline
\end{tabular}

Multiple response: Source: Field survey 2013

\section{Difference in the socio-economic losses among farmers and pastoralists}

Table 6 reveals that a significant difference $(t=3.596, p=0.000)$ exist in the socio-economic loss of farmers and pastoralist as a result of conflict. From the mean distribution it can be deduced that farmers experienced more socioeconomic losses than pastoralists. This further suggests that farmers are more affected in the conflict than the pastoralists. This shows that economic losses, social disturbance and the disruptions to food supply and access associated with conflicts could be disastrous, especially in low-income countries where there are no effective social safety nets. This finding is consistent with that of Ofuoku and Isife (2009) which revealed that many farmers lost part or the whole of their crops during conflicts. Findings by Adisa (2011) in a similar study revealed that farmers experienced more losses than the herdsmen because perception of conflict situation as 'loss' among farmers is more significant than that of herders.

Table 6: Difference in the socio-economic losses of farmers and pastoralists as a result of conflict

\begin{tabular}{llllll}
\hline Variable & Group & t-value & $p$-value & Mean & $\begin{array}{l}\text { Standard } \\
\text { deviation }\end{array}$ \\
\hline Socio economic & Farmers & $3.596^{*}$ & 0.000 & 3.9833 & 0.30853 \\
loss & Pastoralist & & & 2.4833 & 0.28073 \\
\hline
\end{tabular}

${ }^{*} P \leq 0.05$. Source: Field survey, 2013 


\section{Difference in the effect of conflict on extension service delivery to farmers and pastoralist}

Table 7 shows that there is a significant difference in the availability of extension ( $t=3.126, p=0.000)$, adoption of improved technology $(t=1.631, p$ $=0.032)$, and continued use of adopted technology $(t=2.612, p=0.021)$ between farmers and pastoralists. The null hypothesis is therefore rejected. Also, farmers recorded higher mean in each of the components of extension service delivery compared to the pastoralist. This suggests that farmers feel more effects of conflict on agricultural extension service delivery compared to the pastoralists. This study agrees with that of Adisa (2011), who revealed that incessant resource-based conflicts between farmers and herdsmen continue to undermine the impact of agricultural extension service delivery in Nigeria.

Table: 7 Difference in the effect of conflict on extension service delivery to farmers and pastoralist

\begin{tabular}{lllllll}
\hline Components of Extension & Group & t-value & $\mathrm{p}$-value & Df & Mean & $\begin{array}{c}\text { Standard } \\
\text { deviation }\end{array}$ \\
& & & & & & \\
\hline Availability of extension & Farmers & $3.126^{*}$ & 0.000 & 114 & 2.3221 & 1.9136 \\
& Pastoralist & & & & 1.4332 & 1.1879 \\
Access to extension & Farmers & 1.634 & 0.105 & 0.4500 & 0.2807 \\
& Pastoralist & & & 0.2667 & 0.4825 \\
Method of extension & Farmers & 1.301 & 0.210 & 0.2500 & 0.4367 \\
delivery & Pastoralist & & & 0.1500 & 0.4044 \\
Adoption of improved & Farmers & $1.631^{*}$ & 0.032 & 0.6422 & 0.3674 \\
technology & Pastoralist & & & 0.3123 & 0.2441 \\
$\begin{array}{l}\text { Continued use of adopted } \\
\text { technology }\end{array}$ & Farmers & $2.612^{*}$ & 0.021 & 0.4651 & 1.6319 \\
& Pastoralist & & & & 0.3529 & 1.1672 \\
\hline
\end{tabular}

${ }^{*} P \leq 0.05$. Source: Field survey, 2013

\section{Conclusion and Recommendation}

Farmer-pastoralist conflict is definitely having its toll on agricultural extension service delivery in Nigeria. Ironically, it needs not be as intractable as it currently seems. From the study, it was discovered that farmers feel the effect of farmer-pastoralist conflict on agricultural extension service delivery more than the pastoralists. Availability of extension services, most especially among the pastoralists, is low. The study further reveals that farmers suffer more losses from farmer-pastoralist conflicts, especially the economic loss than pastoralist. It is recommended that governmental agencies/ministries responsible for agriculture, lands, geographical information systems, forestry and natural resources ensure proper delineation and regular revision of stock routes. In addition, financial institutions, such as rural development and microfinance banks, and agricultural insurance companies, should work towards financial assistance for victims of farmer-herdsmen conflicts. 


\section{References}

Blench R. M. (2003). The transformation of conflict between pastoralists and cultivators in Nigeria. Paper in press for a special issue of the Journal Africa.ed.M.Montz. Retrieved From http://www.rogerblench.infor/Development/Nigeria Livestock survey.pdf on December 19, 2012.

Food and Agricultural Organization (FAO) (2012). Urban and peri - Agriculture. Food and Agricultural Organization (FAO) of the United Nations, t pp 1923. Retrieved 19 January, 2013 from Integrated Regional Information Network, IRIN, (2010, April 30). Nigeria: Farmer-pastoralists' clash leaves 32 dead. IRIN News.

Ofuoku, A. U. and Isife B. I. (2009). Causes, effects and resolution of farmersnomadic cattle herders conflict in Delta State, Nigeria. International Journal of Sociology and Anthropology. 1(2): 47-54.

Olaleye, R.S., Odutola,J.O., Ojo, M.A., Umar, I.S. and Ndanitsa, M.A. (2010). Perceived effectiveness of conflict resolution methods for improved Farmer-Pastoralist relationship in Chikun Local Government Area of Kaduna State, Nigeria. The Nigerian Journal of Rural Extension and Development, 3:54-58.

Tonah, S. (2006). Farmer -Herder Conflict in Volta region of Ghana. Journal of Social Sciences.2(1),6-10. 